\title{
TTF-1 may not be a Reliable Marker for Differentiating Metastasis from Brain Tumors
}

\author{
TTF-1 Beyin Tümörlerini Metastazdan Ayırmada Güvenilir \\ Bir Belirteç Olmayabilir
}

\author{
Betül ÜNAL', Şenay YILDIRIM², Cem SEZER ${ }^{2}$, Dinç SÜREN ${ }^{2}$ \\ Department of Pathology, ' Akdeniz University, Faculty of Medicine, ANTALYA, TURKEY, ${ }^{2}$ Antalya Education and Research Hospital, ANTALYA, TURKEY
}

\begin{abstract}
Objective: TTF-1 is widely used as an immunohistochemical marker of lung and thyroid tumors. However, TTF-1 expression has been described in tumors from other sites. The presence of TTF-1 expression in primary brain tumors is largely unclear and has not been clearly specified yet. We characterized expression of two TTF-1 clones in primary brain tumors with relevance to tumor types and grades.
\end{abstract}

Material and Method: We studied immunohistochemistry with tissue micro-array, using both clones (8G7G3/1 and SPT24) in 45 primary brain tumors of different types and grades. Our cases consisted of 1 grade I, 7 grade II, 4 grade III, 20 grade IV astrocytic tumors; 9 meningiomas, 2 oligodendrogliomas, 1 schwannoma and 1 medulloblastoma.

Results: We have found TTF-1 nuclear staining using the SPT24 clone in 4 cases ( 3 cases were grade IV and 1 was grade III). Focal and weak staining was seen in three cases and moderate-strong and diffuse staining was seen in one case. All the tumors were negative with clone 8G7G3/1. Clone SPT24 was more sensitive but less specific.

Conclusion: TTF-1 can also be expressed in primary brain tumors, particularly grade III to IV tumors. TTF-1 expression was a rare finding in previous studies, however strong and diffuse staining was not observed until today. We think that TTF-1 nuclear expression in high-grade astrocytic tumors cannot rule out primaries even when diffuse and strong staining. Clinical and pathological parameters should be evaluated together.

Key Words: TTF-1 protein, Brain neoplasms, Astrocytoma

\section{ÖZ}

Amaç: TTF-1 akciğer ve tiroid tümörleri için yaygın kullanılan immünohistokimyasal bir belirteçtir. Ayrıca diğer bölgelerin tümörlerinde de TTF-1 ekspresyonu tanımlanmıştır. Ancak primer beyin tümörlerinde TTF-1 ekspresyonu varlı̆̆ belirsiz ve net olarak ifade edilmemiștir. Biz primer beyin tümörlerinde tümör tipi ve derecesi ile karşılaştırmalı olarak TTF-1'in iki klonuna ait ekspresyonu araştırdık.

Gereç ve Yöntem: Farklı tip ve derecelerde 45 primer beyin tümöründe doku mikro array yöntemi kullanarak her iki TTF-1 klonu (8G7G3/1 ve SPT24) çalışıldı. Olgularımız; astrositik tümör derece I ( $1 \mathrm{olgu})$, derece II (7 olgu), derece III (4 olgu), derece IV (20 olgu) ve 9 meninjiom, 2 oligodendrogliom, 1 schwannom ve 1 medülloblastomdan oluşmaktaydı.

Bulgular: SPT-24 klonunu kullanarak 4 olguda (3 olgu derece 4 ve 1 olgu derece 3) nükleer TTF-1 boyanması bulduk. Üç olgu fokal ve zayıf boyanma, 1 olgu ise orta-şiddetli ve diffüz boyanma şeklinde idi. Tüm tümörler 8G7G3/1 klonu ile negatif idi. SPT24 klonu daha sensitif ama az spesifiktir.

Sonuç: TTF-1 özellikle derece 3 ve 4 olmak üzere primer beyin tümörlerinde eksprese olabilir. TTF-1 ekspresyonu geçmiş çalıșmalarda nadir izlenen bir bulgu olup, șiddetli ve diffüz boyanma günümüze kadar hiç bildirilmemiştir. Yüksek dereceli astrositik tümörlerde TTF-1 nükleer ekspresyonu, boyanma kuvvetli ve diffüz olsa bile primeri dışlayamaz düşüncesindeyiz. Ayırıcı tanı için klinik ve patolojik parametreler birlikte değerlendirilmelidir.

Anahtar Sözcükler: TTF-1 proteini, Beyin neoplazileri, Astrositom

\section{INTRODUCTION}

Thyroid transcription factor-1 (TTF-1) is a $38 \mathrm{kDa}$ DNAbinding protein containing 371 amino acids. It is essential for the development and differentiation of the thyroid, lung and ventral forebrain (1). In the lung, TTF-1 is expressed in type II pneumocytes and Clara cells and regulates Surfactant B protein production (2). However it is expressed

(Turk Patoloji Derg 2014, 30:201-205)

Received : 18.03.2014 Accepted : 28.04.2014 in follicular cells and C cells and regulates the production of thyroglobulin and thyroperoxidase (3). In the brain, TTF- 1 is expressed in the neurons of the hypothalamus and controls the migration of telencephalic interneurons (4).

TTF-1 is widely used as an immunohistochemical marker of lung and thyroid tumors. However, TTF-1 expression has been described in tumors from other sites, particularly

Correspondence: Betül ÜNAL

Akdeniz Üniversitesi Tip Fakültesi, Patoloji Anabilim Dalı,

Dumlupınar Bulvarı, 07070 Konyaaltı, ANTALYA, TURKEY

E-mail: betulunalmd@gmail.com Phone: +90 2422493774 
colorectal carcinoma, gynecological tumors, urothelial carcinoma, prostate, stomach, and salivary gland carcinoma and primary central nervous system tumors (5-8). The presence of TTF-1 expression in primary brain tumors is largely unclear and has not been clearly specified yet.

Two antibody clones are currently widely used for TTF-1 demonstration, 8G7G3/1 and SPT24. Many studies have demonstrated that clone SPT24 is more sensitive but less specific than clone $8 \mathrm{G} 7 \mathrm{G} 3 / 1(5,9-11)$.

In the current study, we investigated the expression of TTF1 in primary brain tumors of various types and grades, using both clones, 8G7G3/1 and SPT24, and compared them with each other. We aimed to clarify the usefulness of TTF-1 for differentiating metastasis from primary brain tumors.

\section{MATERIALS and METHODS}

Case Selection: Formalin-fixed, paraffin-embedded tissue blocks of primary brain tumors were selected from archives of Antalya Training and Research Hospital dated 2008 to 2013. A total of 45 tumors were included in the study. The tumors were classified histologically according to the World Health Organization classification of primary brain tumors.

Tissue Microarray Technique: Tissue microarrays were constructed from archived formalin-fixed, paraffinembedded tissue blocks using a semi-automatic tissue arrayer (Minicore, Alphelys). Tissue cylinders with a diameter of $2 \mathrm{~mm}$ were punched from the tumoral area of the donor block and were transferred to a recipient paraffin block. Sections of 4- $\mu \mathrm{m}$ thickness were cut from tissue microarray blocks.

Immunohistochemistry: Tissue microarray sections were dewaxed in xylene, rehydrated in alcohol, and immersed in 3\% hydrogen peroxide for 10 minutes to suppress endogenous peroxidase activity. Antigen retrieval was performed by heating each section for 30 minutes in 0.01 $\mathrm{mol} / \mathrm{l}$ sodium citrate buffer ( $\mathrm{pH}$ 6.0). After three rinses in phosphate-buffered saline (PBS) for 5 minutes, each section was incubated for 1 hour at room temperature with TTF-1, clones SPT24 (dilution 1:25, Novocastra Lab. Ltd., Newcastle Upon Tyne, UK) and 8G7G3/1 (Dilution 1:1OO, Dako North America, Inc., Cartinteria, CA); washed three times in PBS for 5 minutes; incubated with horseradish peroxidase labeled rabbit anti-mouse immunoglobulin; washed three times; and incubated with a solution of diaminobenzidine $(\mathrm{DAB})$ at room temperature to visualize peroxidase activity.

The immunohistochemical stains of both clones were scored as positive or negative. A positive score was based on focal-diffuse, weak-moderate-strong, nuclear staining.

\section{RESULTS}

In our study, there were 18 (41\%) female and 26 (59\%) male patients, with an age range of 37 to 83 years. Our cases consisted of 1 grade I, 7 grade II, 4 grade III, 20 grade IV astrocytic tumors; 9 meningiomas, 2 oligodendrogliomas, 1 schwannoma and 1 medulloblastoma. TTF-1 expression was seen in a small subset of primary brain tumors with clone SPT24. The primary brain tumor types, which showed positive immunostaining for TTF-1 using the SPT24 clone (4 of 45 cases, $8.8 \%$ ), were grade III-IV glial astrocytic tumors,. All 45 tumors were negative when stained with clone $8 \mathrm{G} 7 \mathrm{G} 3 / 1$. The positive stained cases consisted of 3 (6.6\%) case grade IV glial tumors (glioblastoma) and 1 (2.2\%) case grade III glial tumor (anaplastic astrocytoma). Focal and weak expression was found in 3 cases and 1 glioblastoma showed diffuse and strong staining (Figure $1 \mathrm{~A}, \mathrm{~B}, \mathrm{C})$. Nonspecific cytoplasmic staining was observed in two tumors of which one was meningioma and the other was glioblastoma (Figure 2). Among grade III to IV glial tumors, TTF-1 expression was found in 4 of 45 (8.8\%) cases whereas none of the grade I to II glial tumors expressed TTF-1. The other primary brain tumors were all negative for TTF-1 using the two clones, 8G7G3/1 and SPT2 (Table I).

Table I: Summary of immunohistochemistry results of TTF-1, clones SPT24 and 8G7G3/1

\begin{tabular}{|l|c|r|c|}
\hline & $\begin{array}{c}\text { Total number } \\
\text { of cases }\end{array}$ & \multicolumn{1}{|c|}{$\begin{array}{c}\text { SPT24 } \\
\text { (\%) }\end{array}$} & $\begin{array}{c}\text { 8G7G3/1 } \\
(\%)\end{array}$ \\
\hline Astrocytic tumors & 32 & $4(8.8)$ & $0(0)$ \\
Grade I & 1 & $0(0)$ & $0(0)$ \\
\hline Grade II & 7 & $0(0)$ & $0(0)$ \\
\hline Grade III & 4 & $1(2.2)$ & $0(0)$ \\
\hline Grade IV & 20 & $3(6.6)$ & $0(0)$ \\
\hline Meningioma & 9 & $0(0)$ & $0(0)$ \\
\hline Oligodendroglioma & 2 & $0(0)$ & $0(0)$ \\
\hline Schwannoma & 1 & $0(0)$ & $0(0)$ \\
\hline Medulloblastoma & 1 & $0(0)$ & $0(0)$ \\
\hline
\end{tabular}

\section{DISCUSSION}

TTF-1 expression was first described by Lazzaro et al. in the fetal rat lung, thyroid tissue and neurohypophysis in 1991 (16). TTF-1 is widely used in thyroid and lung tumors in routine practice (17). TTF-1 is a very important marker for distinguishing primary pulmonary adenocarcinomas from metastatic tumors. Jerome MV et al. (17) have reported TTF-1 expression in lung carcinomas, particularly small cell carcinoma, adenocarcinoma and non-mucinous 

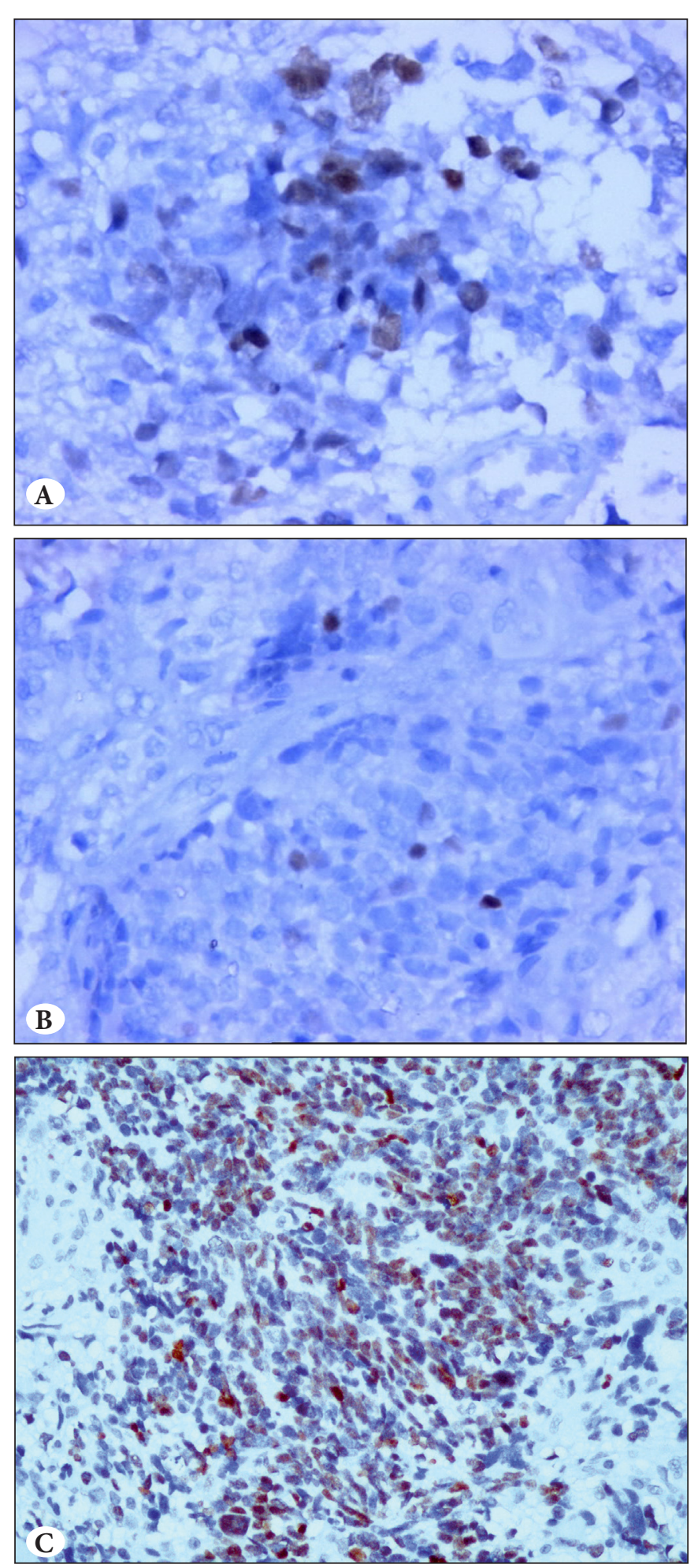

Figure 1: TTF-1 expression in astrocytic tumors (grade III-IV) A) Nuclear staining of tumor cells in glioblastoma was noted using the SPT24 clone (TTF-1; x400). B) Weak focal nuclear staining (TTF-1; x400). C) Moderate diffuse nuclear staining, $\mathrm{x} 400$. The same cases were negative with the $8 \mathrm{G} 7 \mathrm{G} 3 / 1$ clone.

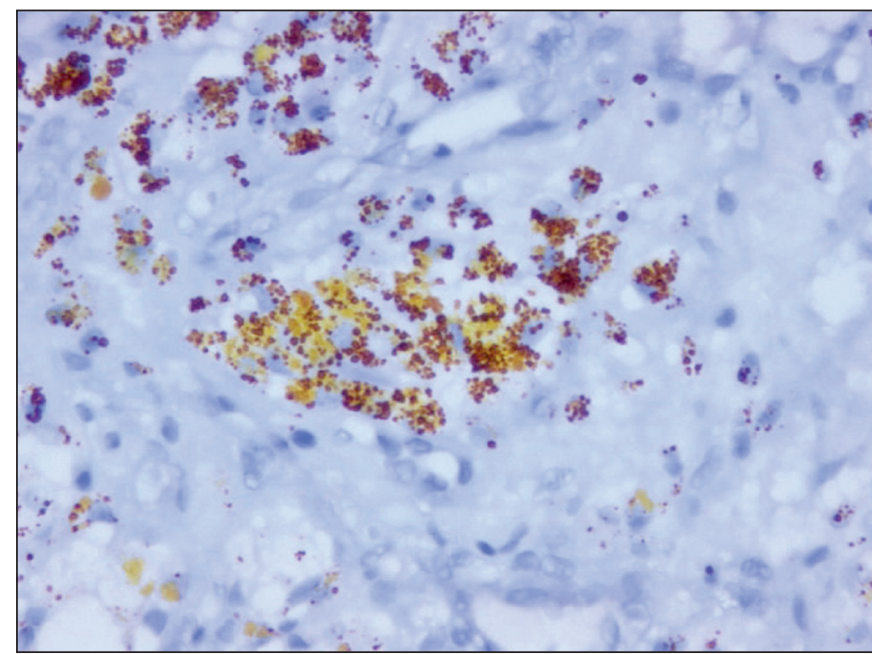

Figure 2: Nonspecific cytoplasmic staining in meningioma (TTF$1 ; \mathrm{x} 400)$.

bronchioloalveolar carcinoma, but no positivity was described in squamous cell carcinoma and mucinous bronchioloalveolar adenocarcinoma. The lung is a common site of metastatic carcinomas. The specificity of TTF-1 for pulmonary lesions has been demonstrated in many studies (18). TTF-1 is a reliable marker for the lung and thyroid, although TTF-1 expression was also identified in urothelial carcinoma, prostate, stomach, salivary gland carcinomas (6), colorectal carcinomas $(6,19)$, ovarian epithelial neoplasms (20) and uterine tumors (21). In addition, TTF1 expression was described in primary central nervous system tumors in a few studies $(5,12-15)$.

The two monoclonal antibodies of TTF-1 that are currently widely used for immunohistochemistry are $8 \mathrm{G} 7 \mathrm{G} 3 / 1$ and SPT24. Clone 8G7G3/1 has been used since 1996, whereas clone SPT24 became available later (5). Most studies have shown high specificity for clone $8 \mathrm{G} 7 \mathrm{G} 3 / 1$, while clone SPT24 seems to have higher sensitivity but less specificity (10). Matoso et al. (6) found $72 \%$ TTF-1 positivity with SPT24 versus $65 \%$ positivity with 8 G7G3/1 in 185 lung adenocarcinomas. Penman et al. (11) reported TTF-1 positivity in 3 out of 6 colorectal carcinomas using clone SPT24 while all of the cases were negative with the other clone.

TTF-1 expression in primary brain tumors was a rare finding in previous studies. As far as we are aware, only 5 studies of TTF-1 expression in primary brain tumors have been published until today (12-15). These studies have reported TTF-1 expression with divergent results. The problem seems to be the use of different clones. However only one study, by Kristensen et al., analyzed TTF-1 with 
both clones, 8G7G3/1 and SPT24. Similarly, we tested primary brain tumors of various types and grades using both TTF-1 clones, 8G7G3/1 and SPT24, and compared them with each other. Our study is the second study using both clones of TTF-1 simultaneously in primary brain tumors to the best of our knowledge.

In chronological order, Zamecnik et al. (12) tested 73 primary brain tumors using clone $8 \mathrm{G} 7 \mathrm{G} 3 / 1$ and TTF-1 was positive in 2 ependymomas. Prok and Prayson (13) tested 50 glioblastomas using the same clone and none was positive for TTF-1. Later, Galloway and Sim (14) found TTF- 1 expression in 13 out of 26 glioblastomas using clone SPT24. Lee et al. (15) studied 17 sellar/supracellar tumors using the SPT24 clone, and all of them were positive. Finally, Kristensen et al. (5) analyzed TTF-1 expression in a series of 155 central nervous system tumors comparing the 8G7G3/ 1 and SPT2 4 clones. TTF-1 expression was observed in 13 cases (8\%) with the SPT24 clone. Expression was found in 10 grade III to IV tumors, 1 central neurocytoma, 1 ependymal tumor and 1 choroid plexus tumor.

In our study, TTF-1 was positive in $4(8.8 \%)$ cases using SPT24 clone and all of the tumors were negative with clone 8G7G3/1. During TTF-1 determination using SPT24 we found weak-focal nuclear staining in 3(6.6\%) cases and strong-diffuse staining in $1(2.2 \%)$ case in our TMA slides. Three (75\%) out of 4 case were glioblastoma (grade IV) and $1(25 \%)$ case was anaplastic astrocytoma (grade III). This is concordant with Kristensen et al. and Galloway and Sim. Kristensen et al. found weak to moderate and focal TTF-1 staining based on clone SPT24 in 13 of 155 cases and 6 of 36 cases were positive in glioblastomas. In addition Galloway and Sim found TTF- 1 expression in 13 of 26 glioblastomas with clone SPT24. In both of the studies no positivity found in all cases with clone 8G7G3/1. Neither Prok and Prayson nor Zamecnik et al. found any expression for TTF- 1 among glioblastomas and astrocytic tumors using clone 8G7G3/1. Furthermore all these findings are in concordance with our study results.

As far as we know, there are 5 studies on TTF-1 expression in primary brain tumors in the literature. However only one study, by Kristensen et al., analyzed TTF-1 with both clones, $8 \mathrm{G} 7 \mathrm{G} 3 / 1$ and SPT24. This is the second study that used both two clones and compared them with each other.

In conclusion, TTF-1 can also be expressed in primary brain tumors, particularly grade III to IV tumors. Boggaram $\mathrm{V}$ reported that TTF-1 is essential for development of the ventral forebrain (1) and can therefore be associated with TTF-1 expression in primary brain tumors. TTF-
1 expression was rarely reported in previous studies but strong and diffuse staining had not been observed until now. We suggest that TTF-1 nuclear expression in high-grade astrocytic tumors cannot rule out primaries even if there is diffuse and strong staining. Clinical and histopathological parameters should be evaluated together for the differential diagnosis. More studies will be needed to better understand the importance of TTF-1 immunoreactivity in primary brain tumors.

\section{REFERENCES}

1. Boggaram V. Thyroid transcription factor-1 (TTF-1/Nkx2.1/ TITF1) gene regulation in the lung. Clin Sci (Lond). 2009;116:2735.

2. Ikeda K, Clark JC, Shaw-White JR, Stahlman MT, Boutell CJ, Whitsett JA. Gene structure and expression of human thyroid transcription factor-1 in respiratory epithelial cells. J Biol Chem. 1995;270:8108-14.

3. Civitareale D, Castelli MP, Falasca P, Saiardi A. Thyroid transcription factor 1 activates the promoter of the thyrotropin receptor gene. Mol Endocrinol. 1993;7:1589-95.

4. Nóbrega-Pereira S, Kessaris N, Du T, Kimura S, Anderson SA, Marín O. Postmitotic Nkx2-1 controls the migration of telencephalic interneurons by direct repression of guidance receptors. Neuron. 2008;59:733-45.

5. Kristensen $\mathrm{MH}$, Nielsen S, Vyberg M. Thyroid transcription factor-1 in primary CNS tumors. Appl Immunohistochem Mol Morphol. 2011;19:437-43.

6. Matoso A, Resnick MB, Wang LJ. Comparison of 2 monoclonal TTF-1 antibodies. Appl Immunohistochem Mol Morphol. 2011;19:384.

7. Dettmer M, Kim TE, Jung CK, Jung ES, Lee KY, Kang CS. Thyroid transcription factor-1 expression in colorectal adenocarcinomas. Pathol Res Pract. 2011;207:686-90.

8. Bisceglia M, Galliani C, Rosai J. TTF-1 expression in breast carcinoma-the chosen clone matters. Am J Surg Pathol. 2011;35:1087-8.

9. Robens J, Goldstein L, Gown AM, Schnitt SJ. Thyroid transcription factor-1 expression in breast carcinomas. Am J Surg Pathol. 2010;34:1881-5.

10. Compérat E, Zhang F, Perrotin C, Molina T, Magdeleinat P, Marmey B, Régnard JF, Audouin J, Camilleri-Broët S. Variable sensitivity and specificity of TTF-1 antibodies in lung metastatic adenocarcinoma of colorectal origin. Mod Pathol. 2005;18: 1371-6.

11. Penman D, Downie I, Roberts F. Positive immunostaining for thyroid transcription factor-1 in primary and metastatic colonic adenocarcinoma: A note of caution. J Clin Pathol. 2006;59: 663-4.

12. Zamecnik J, Chanova M, Kodet R. Expression of thyroid transcription factor 1 in primary brain tumours. J Clin Pathol. 2004;57:1111-3. 
13. Prok AL, Prayson RA. Thyroid transcription factor-1 staining is useful in identifying brain metastases of pulmonary origin. Ann Diagn Pathol. 2006;10:67-71.

14. Galloway M, Sim R. TTF-1 staining in glioblastoma multiforme. Virchows Arch. 2007;451:109-11.

15. Lee EB, Tihan T, Scheithauer BW, Zhang PJ, Gonatas NK. Thyroid transcription factor 1 expression in sellar tumors: A histogenetic marker? J Neuropathol Exp Neurol. 2009;68:482-8.

16. Lazzaro D, Price M, de Felice M, Di Lauro R. The transcription factor TTF-1 is expressed at the onset of thyroid and lung morphogenesis and in restricted regions of the foetal brain. Development. 1991;113:1093-104.

17. Jerome Marson V, Mazieres J, Groussard O, Garcia O, Berjaud J, Dahan M, Carles P, Daste G. Expression of TTF-1 and cytokeratins in primary and secondary epithelial lung tumours: Correlation with histological type and grade. Histopathology. 2004;45:125-34.
18. Kim MJ, Shin HC, Shin KC, Ro JY. Best immunohistochemical panel in distinguishing adenocarcinoma from squamous cell carcinoma of lung: Tissue microarray assay in resected lung cancer specimens. Ann Diagn Pathol. 2013;17:85-90.

19. Xu B, Thong N, Tan D, Khoury T. Expression of thyroid transcription factor-1 in colorectal carcinoma. Appl Immunohistochem Mol Morphol. 2010;18:244-9.

20. Graham AD, Williams AR, Salter DM. TTF-1 expression in primary ovarian epithelial neoplasia. Histopathology. 2006;48:764-5.

21. Zhang PJ, Gao HG, Pasha TL, Litzky L, Livolsi VA. TTF-1 expression in ovarian and uterine epithelial neoplasia and its potential significance, an immunohistochemical assessment with multiple monoclonal antibodies and different secondary detection systems. Int J Gynecol Pathol. 2009;28:10-8. 